\title{
THE EFFECT OF USING SHORT SILENT ANIMATIONS ON EFL LEARNERS' WRITING
}

\author{
Hamid Marashi \\ Islamic Azad University at Central Tehran, Iran \\ E-mail: hamid.marashi@iauctb.ac.ir \\ Hedieh Adiban \\ Islamic Azad University at Central Tehran, Iran \\ E-mail: h.adiban@gmail.com
}

APA Citation: Marashi, H., \& Adiban, H. (2017). The effect of using short silent animations on EFL learners' writing. English Review: Journal of English Education, 5(2), 207-216

Received: 18-04-2017

Accepted: 16-05-2017

Published: 01-06-2017

\begin{abstract}
This study investigated the effect of short silent animations on pre-intermediate EFL learners' writing. A homogenized group of 60 participants was non-randomly chosen and assigned as the control and experimental groups. Those in the control group watched five short animations with dialogue, while those in the experimental group had five short animations which were silent. The procedure lasted 10 sessions. In both groups, the participants were asked to write five writings regarding the subjects of the animations during the term and each of the writings should have contained a minimum of 90 and maximum of 140 words. The participants were provided both oral and written feedback. At the end of the instruction, a sample PET writing posttest was administered to both groups, an independent samples t-test was run on the mean scores of the two groups, and the results $(t=-2.02, p=0.037<0.05)$ revealed that the experimental group outperformed the control group.
\end{abstract}

Keywords: ELT, silent animations, writing

\section{INTRODUCTION}

The unprecedented speed of the technological advancement and diversification of the media (TV, internet, etc.) is making these applications almost inevitable in modern life. Naturally, the same trend would probably prevail in educational settings; that is to say that an abstinence from the utilization of the media in the classroom may seem unacceptable and demotivating to many learners. Hence, there seems to be a growing tendency among teachers - EFL ones being no exception - to use video materials in their classes. In the words of Harmer (2004), visual aids such as films can contribute to enriching the context and enthusiasm in the teaching/learning process in EFL classes.

Perhaps, one readily available such media are animations. These visual materials which technically are synthetic motion pictures through computer simulation are mostly considered to be an advantageous source for language learning (Atkinson, 2002; Cakir, 2006; Craig, Gholson, \& Driscoll, 2002; Tversky, Morrison, \& Betrancourt, 2000). There are of course those who assert that teachers must be cautious in using video aids and not lose the educational purpose in the language classroom (Hegarty, Kriz, \& Cate, 2003; Mayer, Hegarty, Mayer, \& Campbell, 2005; Rockler, 2002; Schnotz \& Rasch, 2005), nevertheless, when carefully selected, films and animations can be a great source of social, cultural, and civilization information. Animations, according to Schnotz and Lowe (2003), can also have a positive psychological effect on learners' understanding through the cognitive and perceptual process as they can provide a 
great amount of "visual and aural stimulation" for learners (Lum, 2009, p. 71).

Furthermore, to avoid any

misunderstanding between watching animations and movies, it is critically important especially for elementary learners to be able to link between the animation pictures and the meaning they intend to convey (Harmer, 2004). Accordingly, the effectiveness of using short and simple animations may be more than long and complex ones; the reason for this argument may be the fact that complex animations might cause learners to be confused and therefore stay behind (Strauss, 1991).

One advantage of using animations can be their positive effect on vocabulary acquisition and therefore leading to writing improvement (Bogaards \& Loafer, 2004) as cited by Marashi and Azarmi (2012). Writing is the most difficult skill for L2 learners to master (Richards \& Renandya, 2002). It is mostly known as a solitary activity that requires a long time and many efforts but produces few results (Bazerman, Little, \& Bethel, 2005) as cited in Marashi and Yavarzadeh (2014).

According to Richards and Schmidt (2002), writing is the result of a complex process of planning, drafting, reviewing, and revising for which many procedures, decision makings, and planning are deployed by the writer and, therefore, learners' writing achievement is related to the extent and how well they have engaged in these processes. Writing is not only a feature of language acquisition; it can be considered as a prerequisite for effective communication across a range of human activities. According to Hacker (1998), writers must learn how to plan, organize, draft, revise, and edit; they must also consider audience, purpose, and genre during the writing process. Possessing writing skills is a mark of distinction but it can also indicate other attributes and inclinations, one being powerful academic success (Graham \& Harris, 2005) because it can help writers to think, remember, observe, and also communicate (Barrass, 1995).

Writing is a cognitive and dynamic process and cannot be memorized like the other static bodies of knowledge (Goddard \& Sendi, 2008; Rao \& Prasad, 2009, as cited in Marashi \& Dadari, 2012). Perhaps one striking challenge is that many students consider writing as an assignment they are required to do for school, as "opposed to textual expression they engage in their own time" (Purcell, Buchanan, \& Friedrich, 2013, p. 14). Accordingly, students need motivation to write about the subjects they are asked. Using animation can thus be a useful source and not only considered as fun but also as a visual learning aid to help learners have some brainstorming in their mind and a motivational teaching tool for both practicing and stimulating the writing skill (Katchen, 2002).

The literature is perhaps abundant with research studies conducted on the impact of using videos in the language classroom. In their research, Kayaoglu, Dag Akbas, and Ozturk (2011) looked for the effect of animation on learners' vocabulary achievement; the results indicated that using animation could have a positive impact on students' achievement. Zulfadlan and Arifin (2013) investigated the effect of animation movies on sixth grade students' narrative writing. The results indicated that animation bore a significantly positive impact on learners' narrative writing. Chan and Black (2005) studied the comparative effect of animation and static visuals on language learning thus concluding that learners convey better understanding and comprehension through animation.

In addition, Baratta and Jones (2008) have worked on the idea of the effect of films on academic writing skills. Although there was not an absolute improvement, the final result showed a positive feedback taken from most of the learners. Also, Ghaedsharafi and Bagheri (2012) sought into whether the three different 
presentations of audiovisual, visual, and audio could affect EFL learners' writing ability. The results showed that the audiovisual group performed better than the other two groups in their writings.

Regarding what has been discussed so far, the researchers sought to respond to the following research question: Does using short silent animations have any significant effect on EFL learners' writing?

\section{METHOD}

For the purpose of this study, 90 female pre-intermediate EFL learners within the age group of 18 to 30 from a language school in Tehran were considered and based on their performance on a sample Cambridge ESOL Preliminary English Test (PET), 60 of them were chosen and non-randomly assigned to two experimental and control groups of 30 . There were also 30 female participants with almost the same language proficiency background as the 90 learners mentioned above who sat for the piloting of the test.

Two tests, a course book, and 10 animations were used during the course. A sample PET (Preliminary English Test) was administered for the participant selection process as described above. The speaking section of the PET was not administered and both researchers whose inter-rater reliability had been established in the piloting phase ( $\mathrm{r}$ $=0.787, p=0.0001<0.01)$ scored the writing papers. In addition, the writing paper of another sample PET was used as the posttest and administered to both groups at the end of the course.

The participants in both control and experimental groups studied PreIntermediate English Result course book and Basic Oxford Word Skills book. Both groups were presented with five short animations. The control group watched five short animations with dialogue while the experimental group had five silent short animations. The maximum duration of each animation was 10 minutes. The context was mostly fiction and the genre consisted of comedy, romance, horror, and adventure. The titles of the five short silent animations were: The Blue Umbrella, The Ugly Duckling, Alma, Partly Cloudy, and Worlds Apart. There were three short animations by the name of: The Guardian Tale, Legend of Mordue, and The Hawaiian Vacation. The other two were chosen from long animations: Inside Out, from 01:07:02 to 01:13:28, and also Big Hero 6, from 00:27:00 to $00: 36: 55$, regarding the themes and context mentioned earlier.

To commence the study, the teacher of both groups (one of the researchers) piloted a sample PET among 30 female EFL learners alongside the item analysis reported earlier. The inter-rater reliability of the two raters scoring the writing section was established too (following a comprehensive mutual briefing they held together on how to score the writings) and the test was thence administered among 90 learners with 60 of them whose scores fell one standard deviation above and below the mean chosen as the participants of this study and assigned randomly to two groups of control and experimental in which each group containing 30 learners.

Both groups participated in the course three days a week for 20 sessions. In the last 20 minutes of five sessions during the course, each group watched five different short animations (silent ones for the experimental group and animations with dialogue for the control group, as described above). The animations covered the same subjects for both groups for a maximum duration of 10 minutes. If necessary, the teacher used to elicit the animation's main idea. The students were not bound to follow any particular style in their writings and were free in choosing the writing genre as long as they followed the necessary rules and grammars provided by their course book and teacher.

The students in both groups subsequently underwent the writing process for 10 minutes and then gave their works to the teacher. The writings should have 
contained at least 90 and a maximum of 140 words. Their papers were corrected by the two researchers; the next session, the students received written and - if necessary - oral feedback. For the oral feedback, the teacher wrote the learners' grammatical and spelling errors on the board, without mentioning any names, either explaining them herself or asking the learners to correct them.

In the control group, the learners watched five short animations with a dialogue and the participants in the experimental group were presented five short silent animations. The students were encouraged to be creative: to use their imagination in their writings and not solely write a summary of the animation. Their writings could be a story and even the learners' own experience regarding the subject of the animation. Each of their writings should have contained a maximum of 140 words and were submitted after 10 minutes. On the $18^{\text {th }}$ session of the course, the participants in both groups sat for the same posttest.

\section{RESULTS AND DISCUSSION Participant Selection}

As described above, the first step in the participant selection was piloting the test. Following the piloting, the mean and standard deviation of the raw scores were calculated: 49.90 and 9.69 , respectively. The reliability of the test scores (estimated through the KR-21 procedure) gained by the participants on the pilot PET was also 0.83. Next, the piloted PET was administered for participant selection. Table 1 shows the descriptive statistics of this administration with the mean being 62.56 and the standard deviation 13.51 , respectively.

Table 1. Descriptive Statistics of the PET Administration

\begin{tabular}{lccccc}
\hline & N & Minimum & Maximum & Mean & Std. Deviation \\
\hline PET Administration & 90 & 35 & 85 & 62.56 & 13.506 \\
\hline Valid N (listwise) & 90 & & & & \\
\hline
\end{tabular}

Among the 90 students who took the PET, the researchers selected 60 who scored between one standard deviation above and below the mean. As the students in the language school came from intact groups and the researchers did not have the luxury of random sampling, they had to make sure that the 30 learners in each of the two groups bore no significant difference in terms of the dependent variable of this study (writing skill) prior to the treatment.
To this end, they checked whether the mean scores of the two groups on the writing section of the PET administered earlier bore any significant difference or not. First, however, the descriptive statistics of the scores obtained by these 60 learners on the PET writing section are presented (Table 2). As shown, the mean and standard deviation of the control group were 15.90 and 3.54, respectively, while those of the experimental group were 16.02 and 4.61 , respectively.

Table 2. Descriptive Statistics of the Writing Scores of the Two Groups on the PET Administration

\begin{tabular}{lccccccc}
\hline & N & Minimum & Maximum & Mean & $\begin{array}{c}\text { Std. } \\
\text { Deviation }\end{array}$ & \multicolumn{2}{c}{ Skewness } \\
\hline & Statistic & Statistic & Statistic & Statistic & Statistic & Statistic & Std. Error \\
\hline $\begin{array}{l}\text { Control Group Pre- } \\
\text { Writing }\end{array}$ & 30 & 10.00 & 20.00 & 15.900 & 3.536 & .068 & .427 \\
\hline
\end{tabular}




\begin{tabular}{lccccccc}
\hline $\begin{array}{l}\text { Experimental Group } \\
\text { Pre-Writing }\end{array}$ & 30 & 10.00 & 20.00 & 16.02 & 4.609 & .664 & .427 \\
\hline Valid N (listwise) & 30 & & & & & & \\
\hline
\end{tabular}

Going back to Table 2, the skewness ratios of both groups ( 0.16 and 1.54$)$ fell within the acceptable range of \pm 1.96 , thus, signifying that, the score distributions in both groups represented normality.

Therefore, running an independent samples $t$-rest was legitimized.

Table 3. Independent Samples t-Test of the Mean Scores of Both Groups in Their Writing Prior to the Treatment

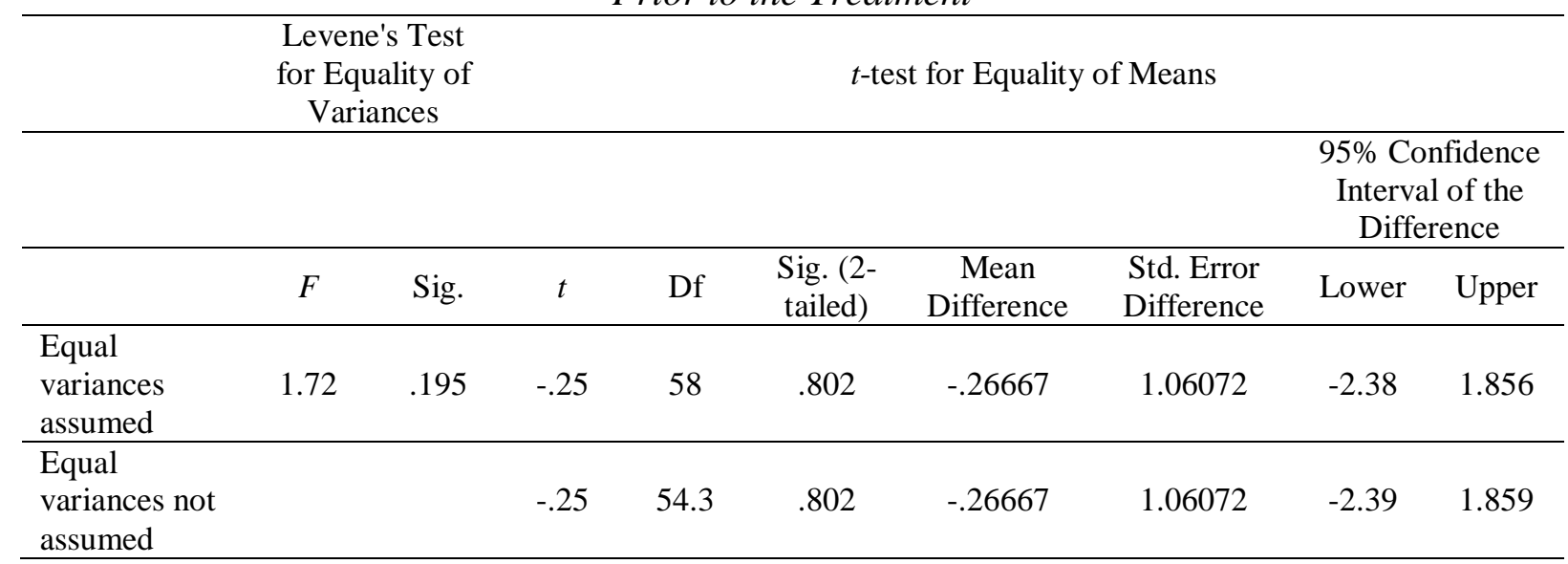

As Table 3 above indicates, with the $F$ value of 1.722 at the significance level of 0.195 being larger than 0.05 , the variances between the two groups were not significantly different. Therefore, the results of the $t$-test with the assumption of homogeneity of the variances were reported here. The results $(t=-$ $0.251, p=0.802>0.05)$ indicate that there was no significant difference between the mean scores of the two groups at the outset; consequently, any probable differences at the end of the treatment could be attributed to the effect of the treatment.

\section{Posttest}

The researchers administered the writing posttest (described in detail earlier) among the two experimental and control groups once the treatment was completed. Table 4 below displays the descriptive statistics of this administration. As shown, the mean and standard deviation of the control group were 15.08 and 2.21, respectively, while those of the experimental group were 16.23 and 2.18 , respectively.

Table 4. Descriptive Statistics for the Posttest in Both Groups

\begin{tabular}{lccccccc}
\hline & N & Minimum & Maximum & Mean & $\begin{array}{c}\text { Std. } \\
\text { Deviation }\end{array}$ & \multicolumn{2}{c}{ Skewness } \\
\hline & Statistic & Statistic & Statistic & Statistic & Statistic & Statistic & Std. Error \\
\hline $\begin{array}{l}\text { Control Group } \\
\text { Posttest }\end{array}$ & 30 & 10 & 18 & 15.08 & 2.213 & -.806 & .427 \\
$\begin{array}{l}\text { Experimental Group } \\
\text { Posttest }\end{array}$ & 30 & 10 & 20 & 16.23 & 2.184 & -.743 & .427 \\
\hline Valid N (listwise) & 30 & & & & & & \\
\hline
\end{tabular}




\section{Testing the Null Hypothesis}

To verify the null hypothesis of the study, the researchers intended to conduct the independent samples $t$-test. Going back to Table 4 , the skewness ratios of both groups fell within the acceptable range of \pm 1.96 (-1.89 and -1.74$)$, thus, signifying that, the score distributions in both groups represented normality. Therefore, running a $t$-rest was legitimized.

Table 5. Independent Samples t-Test on the Mean Scores of Both Experimental Groups

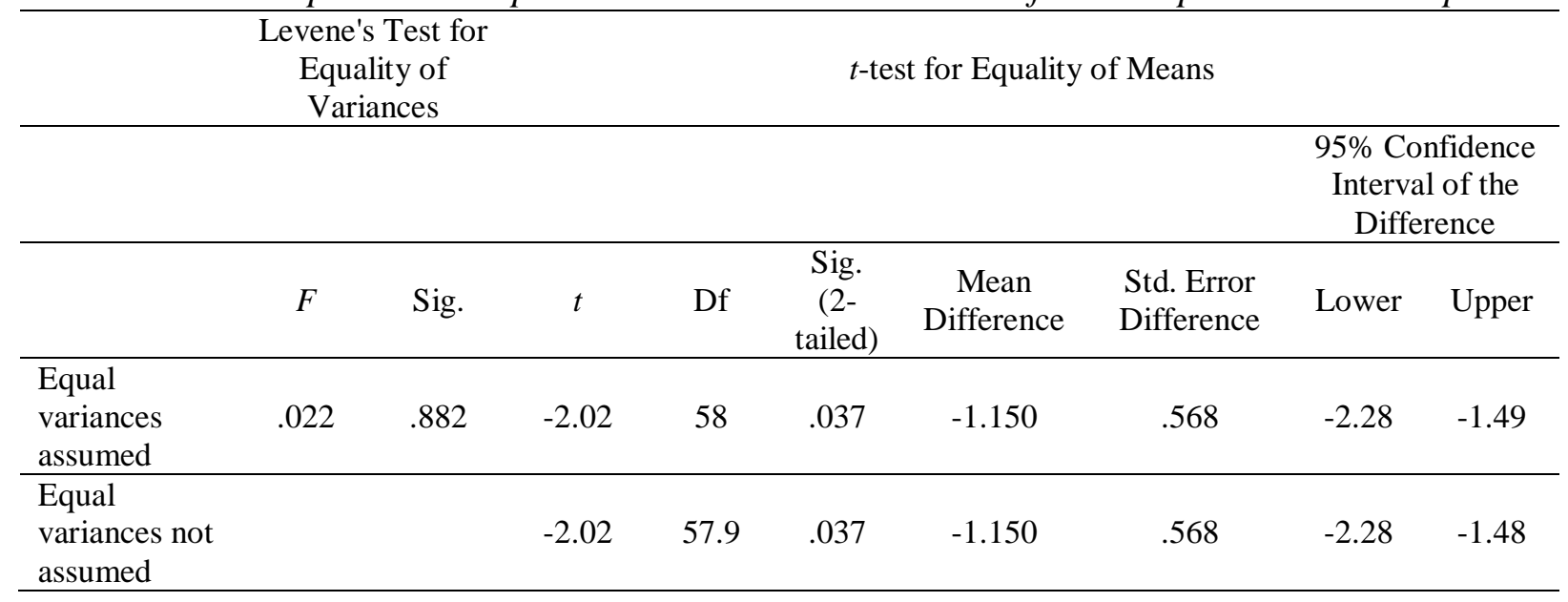

As Table 5 above indicates, with the $F$ value of 0.022 at the significance level of 0.882 being larger than 0.05 , the variances between the two groups were not significantly different. Therefore, the results of the $t$-test with the assumption of homogeneity of the variances were reported here. The results $(t=-2.02, p=0.037<$ $0.05)$ indicate that there was a significant difference between the mean scores of the two groups at the posttest.

It can thus be concluded that the presupposed null hypothesis was rejected meaning that the experimental group who gained a higher mean score on the posttest outperformed the control group in this study.

Following the rejection of the null hypothesis, the researchers were interested to know how much of the obtained difference could be explained by the variation in the two levels of the independent variable. To determine the strength of the findings of the research, that is, to evaluate the stability of the research findings across samples, effect size was also estimated to be 0.67 . According to Cohen
(1988, p. 22), this is a moderate effect size. Therefore, the findings of the study could be moderately generalized.

Regarding the studies done in recent years, the positive effect of media (animation and movies) on learning different skills has become apparent (Ghaedsharafi \& Bagheri, 2012; Maneekul, 2002; Marvasti \& Mosavi, 2015; Xhemaili, 2013). As Fitria, Jismulatif, and Syarfi (2015) noted, using animation films can improve reading comprehension and many language skills such as vocabulary, comprehension, and sequencing. According to the results gathered by the tests in her research, Kumalawati (2014) concluded that silent films can improve learners' narrative writing ability.

Hsu (2011) believes that having multimedia technology can be useful to improve writing abilities in classes. It should also be considered that video can provide learners with content, context, and language (Shahani \& Tahriri, 2015); therefore, using it would be interesting for them. It can also be concluded that having funny animated pictures can result in higher 
learning rate in time compared to annotated funny pictures (Ghaderi \& Afshinfar, 2014).

This study focused on the visual aspect of short silent animations. As Champoux (1999) claims, movies can help inexperienced learners to have a feeling of reality through visual aids which can also be helpful to instructors and teachers as Mannan (2005) points out. Throughout the research, it was clearly observed that the learners in the experiment group were more eager and interested to find and use new vocabularies and were more creative in their writing while those in the control group were mostly bound to the vocabularies they could understand and find in motion pictures and though being creative, they were mostly under the influence of the dialogues and the theme of the animation with speech.

The higher writing scores of experimental group compared to those of the control group in this research showed that watching silent animations had more effect on the writing quality than those with dialogues.

\section{CONCLUSION}

The main pedagogical implication of this study is yet further emphasis on using authentic materials especially animations to encourage students to participate more voluntarily in the writing process. In the researchers' experience, most learners consider writing classes were boring; hence, using animation can probably make them more interested in the parts that are taught. Moreover, using silent animation would help the learners to focus more on the issue which is presented in the motion picture and less in the dialogues and, therefore, it would further motivate them in trying to use as many new vocabularies as possible.

The important thing to note when learners are using silent animations is that they would not get lost in the story as these animations tend to encourage them to use their imagination and previous knowledge and experiences to come up with a proper writing. Throughout this study, both groups demonstrated improvement but most of the participants in the control group were more bound to the animation and the dialogues used in them while the members of the experimental group were more interested in using new ideas and experiences rather than the summary of the story.

ELT schools may think of being able to provide the proper technology and time for these classes which would not only be helpful for writing but also could cover different skills such as reading and speaking. Animation has been regarded as an appealing way for teaching and is considered as a tool which can make learning more fun. Learners also find this material to be more interesting and motivating. At the same time, writing is viewed as a difficult task but an important subject to be learned; therefore, in order to gain optimal results, teachers in general can try to be creative and find innovative animations to show in classes for teaching this skill to students thereby encouraging them to absorb the lessons more effectively.

\section{REFERENCES}

Atkinson, R. K. (2002). Optimizing learning from examples using animated pedagogical agents. Journal of Educational Psychology, 94(2), 416-427.

Baratta, A. \& Jones, S. (2008). Using film to introduce and develop academic writing skills among UK undergraduate students. Journal of Educational Enquiry, 8(2), 15-37.

Barras, R. (1995). Students must write: A guide to better writing in coursework and examination. London: Longman.

Cakir, I. (2006). The use of video as an audio-visual material in foreign language teaching classroom. TOJET: The Turkish Online Journal of Educational Technology, 5(4), 67-72.

Champoux, J. E. (1999). Film as a teaching resource. Journal of Management Inquiry, 8(2), 206-217.

Chan, M. S., \& Black, J. B. (2005). Effect of presentation mode and visualization type on understanding dynamic physical processes. Paper presented at the American Educational Research Association annual meeting, Montreal, Canada. 
Cohen, J. (1988). Statistical power analysis for the behavioral sciences ( $2 n d$ ed.). Hillsdale, $\mathrm{NJ}$ : LEA.

Craig, S. D., Gholson, B., \& Driscoll, D. M. (2002) Animated pedagogical agents in multimedia educational environments: Effects of agent properties, picture features, and redundancy. Journal of Educational Psychology, 94(2), 428434

Fitria, Z., Jismulatif, M., \& Syarfi, H. M. (2015). Using animation films to improve the ability of the second grade students of SMAN 1 BANTAN in writing legend. Journal Online Mahasiswa, $3(1)$.

Ghaderi, V., \& Afshinfar, J. (2014). A comparative study of the effects of animated versus static funny pictures on Iranian intermediate EFL students' intake and retention of idioms. Procedia-Social and Behavioral Sciences, 98, 522-531.

Ghaedsharafi, M., \& Bagheri, M. (2012). Effects of audiovisual, audio, and visual presentations on EFL learners' writing skill. International Journal of English Linguistics, 2(2), 113-121.

Goddard, Y. L., \& Sendi, C. (2008). Effects of selfmonitoring on the narrative and expository writing of four fourth-grade students with learning disabilities. Reading and Writing Quarterly, 24(4), 408-433.

Graham, S., \& Harris, K. R. (2005). Writing better: Effective strategies for teaching students with learning difficulties. Baltimore, MD: Paul H. Brookes.

Hacker, D. J. (1998). Definitions and empirical foundations. In D. J. Hacker, J. Dunlosky, \& A. C. Graesser (Eds.), Metacognition in educational theory and practice (pp. 1-23). Mahwah, NJ: LEA.

Harmer, J. (2004). How to teach writing. New York: Longman.

Hegarty, M., Kriz, S., \& Cate, C. (2003). The roles of mental animations and external animations in understanding mechanical systems. Cognition \& Instruction, 21(4), 325-360.

Hsu, W. (2011). You-Tube in an EFL composition class. Arab World English Journal, 2(2), 91-132.

Katchen, J. E. (2002). Video in ELT-theoretical and pedagogical foundations. Proceedings of the 2002 KATE (The Korea Association of Teachers of English) International Conference, 256-259.

Kayaoglu, M. N., Dag Akbas, R. D., \& Ozturk, Z. (2011). A small scale experimental study: Using animations to learn vocabulary. TOJET: The Turkish Online Journal of Educational Technology, 10(2), 24-30.

Kumalawati, A. N. (2014). The writing ability in narrative text of the $10^{\text {th }}$ grade students of senior high school taught by using silent film.
Unpublished doctoral dissertation, Universitas Muria Kudus.

Lum, C. H. (2009). Teaching world music through feature films. Music Educators Journal, 95(3), $71-75$

Maneekul, J. (2002). Use of authentic material and tasks to enhance English listening skill for undergraduate students majoring in teaching English at Faculty of Education, Chiang Mai University. Unpublished master's thesis, Chiang Mai University.

Mannan, A. (2005). Modern education: Audio-visual aids. New Delhi: Anmol.

Marashi, H., \& Azarmi, A. (2012). The comparative effect of presenting words in semantically related and unrelated sets in intentional and incidental learning contexts on Iranian EFL learners' vocabulary learning. Journal of Second Language Teaching and Research, 1(2), 71-89.

Marashi, H., \& Dadari, L. (2012). The impact of using task-based writing on EFL learners' writing performance and creativity. Theory and Practice in Language Studies, 2(12), 2500-2507.

Marashi, H., \& Yavarzadeh, E. (2014). Using critical discourse analysis instruction in argumentative and descriptive writing classes. Issues in Language Teaching, 3(2), 209-236.

Mayer, R. E., Hegarty, M., Mayer, S., \& Campbell, J. (2005). When static media promote active learning: Annotated illustrations versus narrated animations in multimedia instruction. Journal of Experimental Psychology: Applied, 11(4), 256265.

Mosavi, T. M., \& Marvasti, F. T. (2015). The effects of animation usage on first grade reading. British Journal of Education, Society \& Behavioural Science, 10(2), 1-10.

Purcell, K., Buchanan, J., \& Friedrich, L. (2013). The impact of digital tools on student writing and how writing is taught in schools. Washington, DC: Pew Research Center.

Richards, J. C., \& Renandya, W. A. (2002). Methodology in language teaching: An anthology of current practice. Cambridge: Cambridge University Press.

Richards, J. C., \& Schmidt, R. (2002). Longman dictionary of language teaching and applied linguistics. London: Pearson Education.

Rockler, N. R. (2002). Overcoming 'it's just entertainment': Perspective by incongruity as strategy for media literacy. Journal of Popular Film and Television, 30(1), 16-22.

Schnotz, W., \& Lowe, R. K. (2003). External and internal representations in multimedia learning. Learning and Instruction, 13(2), 117-123.

Schnotz, W., \& Rasch, T. (2005). Enabling, facilitating, and inhibiting effects of animations in multimedia learning: Why reduction of cognitive 
ENGLISH REVIEW: Journal of English Education

Volume 5, Issue 2, June 2017

load can have negative results on learning. Educational Technology Research and Development, 53(3), 47-58.

Shahani, S., \& Tahriri, A. (2015). The impact of silent and freeze-frame viewing techniques of video materials on the intermediate EFL learners' listening comprehension. SAGE Open, 5(2).

Strauss, R. (1991). Some basics of screen design for television-based multimedia. Multimedia and Videodisc Monitor, 2(11), 24-28.

Tversky, B., Morrison, J. B., \& Betrancourt, M. (2000). Animation: Can it facilitate? International
p-ISSN 2301-7554, e-ISSN 2541-3643

https://journal.uniku.ac.id/index.php/ERJEE

Journal of Human-Computer Studies, 57(4), $247-$ 262.

Xhemaili, M. (2013). The advantages of using films to enhance students' reading skills in the EFL classroom. Academic Journal of Interdisciplinary Studies, 4(13), 62-66.

Zulfadlan, A., \& Arifin, T. M. (2013). Improving grade $\mathrm{x}$ students' achievement in writing narrative paragraph through animation movie. Journal of English Language Teaching of FBS-Unimed. 2(1), 1-16. 


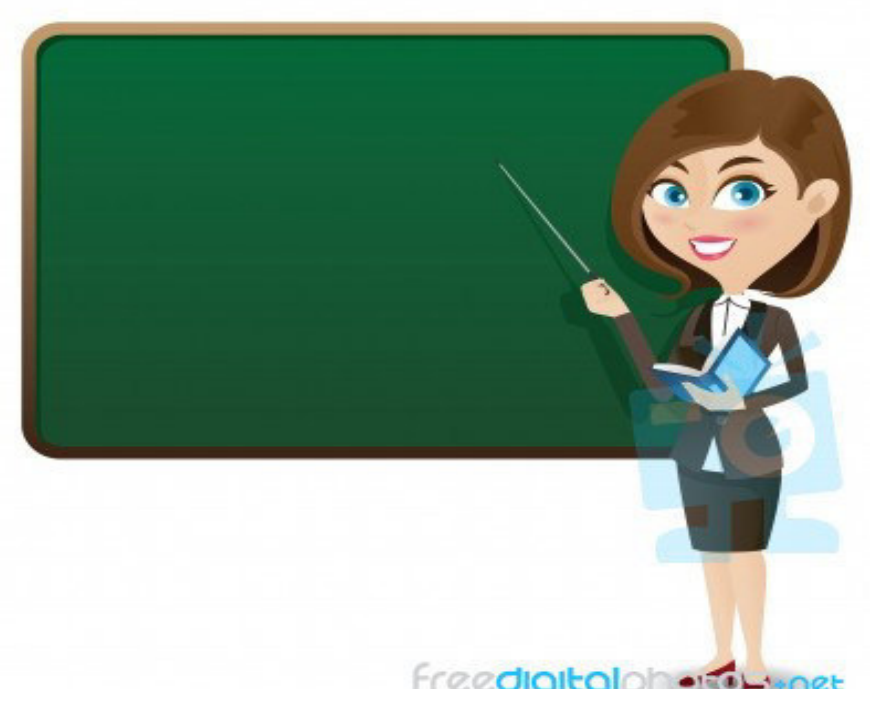

\section{Teacher}

A teacher asks her class, "If there are 5 birds sitting on a fence and you shoot one of them, how many will be left?" She calls on little Johnny. He replies, "None, they all fly away with the first gun shot" The teacher replies, "The correct answer is 4, but I like your thinking." Then, Little Johnny says "I have a question for YOU. There are three women sitting on a bench having ice cream: One is delicately licking the sides of the triple scoop of ice cream. The second is gobbling down the top and sucking the cone. The third is biting off the top of the ice cream. Which one is married?" The teacher, blushing a great deal, replied "Well I suppose the one that's gobbled down the top and sucked the cone" To which Little Johnny replied, "The correct answer is the one with the wedding ring on, but I like your thinking."

(Source: http://www.study-express.ru/humour/funny-stories.shtml, picture: www.google.co.id) 